\title{
Havaintoja Pohjoismaiden Geenipankin Suomesta keräämistä ohranäytteistä
}

\author{
OSMO ULVINEN \\ Valtion siementarkastuslaitos, Maneesikatu 7, \\ 00170 Helsinki
}

\section{Observations of the barley samples collected from Finland by the Nordic Gene Bank}

Osmo Ulvinen

Finnish State Seed Testing Station, SF-00171 Helsinki

\begin{abstract}
Nordic Gene Bank 1979-83 were examined by the Finnish Seed Testing Station (Tables 1-5). The cultivar or type composition of the most significant samples is given in table 6.

These 22 samples, about $36 \%$ of all the samples examined, are likely to have such hereditary characters that are not available elsewhere. The rest of the samples were recognized to be named cultivars still available mainly the Finnish cultivars Otra and Pirkka or lots having lost their germinability. The main group in table 6 consists of $n 4$-rowed», i.e. lax-eared six-rowed barleys of different types. The samples 13 and 14 were identified to be most likely the Swedish Ásabarley. There may be some components of old varieties (Lapinohra, Pertunohra, Vega, Edda, Ảsa etc.) among the other samples as well, but mostly they seemed to be so-called land-varieties. In the 2-rowed barleys in the table dominates the type that is very similar to the oldest Finnish barley cultivar, Piikkiönohra, selected from a land-variety. As the preliminary comparisons of the types show (Tables $7-8$ ) the material was generally very homogeneous but there was also some variation both between and with in the samples.
\end{abstract}

Index words: identification of barley varieties, gene banks, local barley varieties of Finland

Valtion siementarkastuslaitos on Pohjoismaiden Geenipankin (NGB) toivomuksesta tutkinut joukon sen Suomesta keräämiä ohranäytteitä. Tutkimuksen tarkoituksena on yrittää selvittää näytteiden lajikekoostumus ja siltä osalta, jota ei kyetä nimetyiksi lajikkeiksi tunnistamaan, morfologisesti toisistaan poikkeavat ryhmät.

\section{Tarkastusmenetelmät ja morfologinen ryhmittely}

Näytteiden jyvien ominaisuudet on ensin tarkastettu laboratoriossa tutkimalla joko näyte kokonaan tai osa siitä. Jos tarkastuksessa on todettu muoto-opillisesti poikkeavia jyviä, on nämä erotettu omiksi ryhmikseen. 
Laboratoriotarkastuksen tuloksia on täydennetty harkinnan mukaan kenttäkoetarkastuksella. Jos laboratoriossa on näytteestä erotettu eri jyväryhmiä, on nämä kylvetty koekentälle erikseen.

Aineisto kylvettiin yhden rivin ruuduiksi, joiden pituus oli $6 \mathrm{~m}$ tai vähemmän, jos jyviä ei riittänyt täydelle riville. Ruutujen väli oli $34 \mathrm{~cm}$. Tämän lisäksi kylvettiin näytteistä, joista oli enemmän jyviä käytettävissä, $7.2 \mathrm{~m}^{2}: \mathrm{n}$ ruudut. Näissä oli kuusi riviä, joiden pituus oli $6 \mathrm{~m}$ ja riviväli $20 \mathrm{~cm}$ sekä ruutujen väli $30 \mathrm{~cm}$. Samaa tyyppiä olevat näytteet kylvettiin vierekkäin siten, että samoilta alueilta saatu aineisto oli mahdollisimman lähellä toisiaan. Verrannelajikkeina olivat Otra ja Balder.

Tahoisuusryhmityksessä on ohrat jaettu 2-, 4- ja 6-tahoisten ryhmään (ULVINEN 1963). Tyvisukasen karvojen pituuden ja jyvän sivuselkäsuonien väkäsellisyyden mukaisessa ryhmittelyssä on käytetty $\alpha, \beta, \vartheta$ ja $\delta$ merkkien (SAUli 1927, KoRPINEN 1943) sijasta kirjaimia a, b, c ja d, jolloin:
$\mathrm{a}=$ tyvisukanen pitkäkarvainen, sivuselkäsuonet väkäsettömät
b = tyvisukanen pitkäkarvainen, sivuselkäsuonet väkäselliset
$\mathrm{c}=$ tyvisukanen lyhytkarvainen sivuselkäsuonet väkäsettömät
$\mathrm{d}=$ tyvisukanen lyhytkarvainen sivuselkäsuonet väkäselliset

Maininta "pilosum» tarkoittaa karvojen esiintymistä jyvän vatsavaon reunoissa (HUNTER 1952, ULVINEN 1972).

\section{Eri keräysaineistojen tutkimustulokset}

\section{Vuosi 1979 (Taulukko 1)}

Vuoden 1979 keräykset suuntautuivat Pohjois-Suomeen (Liite 1). Sieltä toivottiin löydettävän runsaasti jo muualta kadonnutta aineistoa. Siementarkastuslaitos tutki näytteistä 12 sekä myöhemmin lisäksi kaksi Ruotsin puolelta (Överkalix) kerättyä näytettä. Taulukossa käytetty tunnus on Pohjoismaiden Geenipankin näytteelle keräysvaiheessa antama merkki.

Useimpien näytteiden itävyys oli varsin hyvä. Tämä osoittaa, että kysymys on viljelyssä olevasta tavarasta eikä vuosia laarissa säilytetystä jätteestä. Suurin osa näytteistä oli Otra-ohraa, johon oli enemmän tai vähemmän sekoittunut muuta ohraa. Näytteen $3 \mathrm{Ot}$ ra ja näytteen 9 Hankkija-673 kasvoivat kerran lisättynä vuonna $19817.2 \mathrm{~m}^{2}$ :n ruutuina verrannelajikkeiden vieressä. Mitään eroavuutta ei havaittu. Tyypeistä, joita ei voitu tunnistaa lajikkeiksi, oli yleisin 4-tahoinen dohra. Tämä oli odotettavaakin, koska SAULın (1927) tutkimuksien mukaan maatiaisohriemme pääosa on juuri tätä tyyppiä. Kolmessa näytteessä tavattu 4-tahoinen b-ohra on oloissamme varsin harvinainen tyyppi ja sitäkin harvinaisempi on näytteessä 12 tavattu 4-tahoinen a-ohra (Kuva 1).

\section{Vuosi 1980 (Taulukko 2)}

Vuoden 1980 näytteet ovat Itä- ja KaakkoisSuomesta (Liite 1). Näistä siementarkastuslaitos tutki 16 sekä lisäksi yhden, kevätrukiista löydetyn yksilön.

Aineisto oli hyvin Pirkka-voittoista. Samoin Otraa esiintyi runsaasti, mutta myös uudempia lajikkeita kuten Teemua, Etua ja Pomoa. Aineiston ehdottomasti mielenkiintoisin näyte on nro 16. Tämän Savitaipaleelta

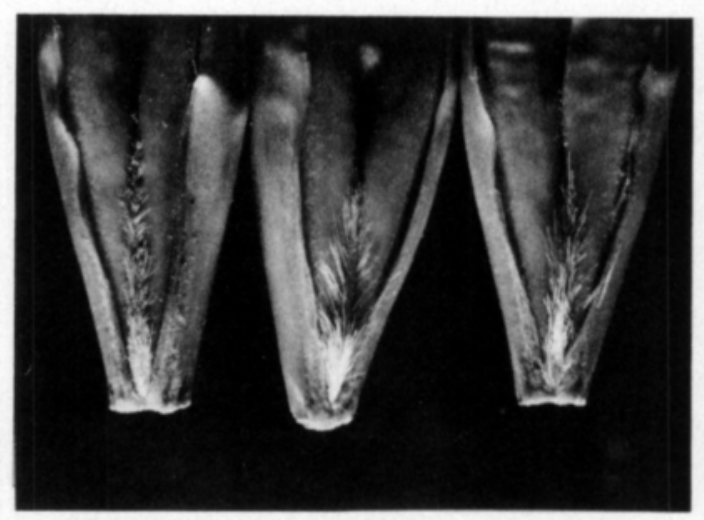

Kuva 1. Näytteen 12 nelitahoisten a- (oik.), b- ja dtyyppien tyvisukaset.

Fig. 1. The rachilla of the 4-rowed $a$ - (right), b-and d-types from sample 12. 


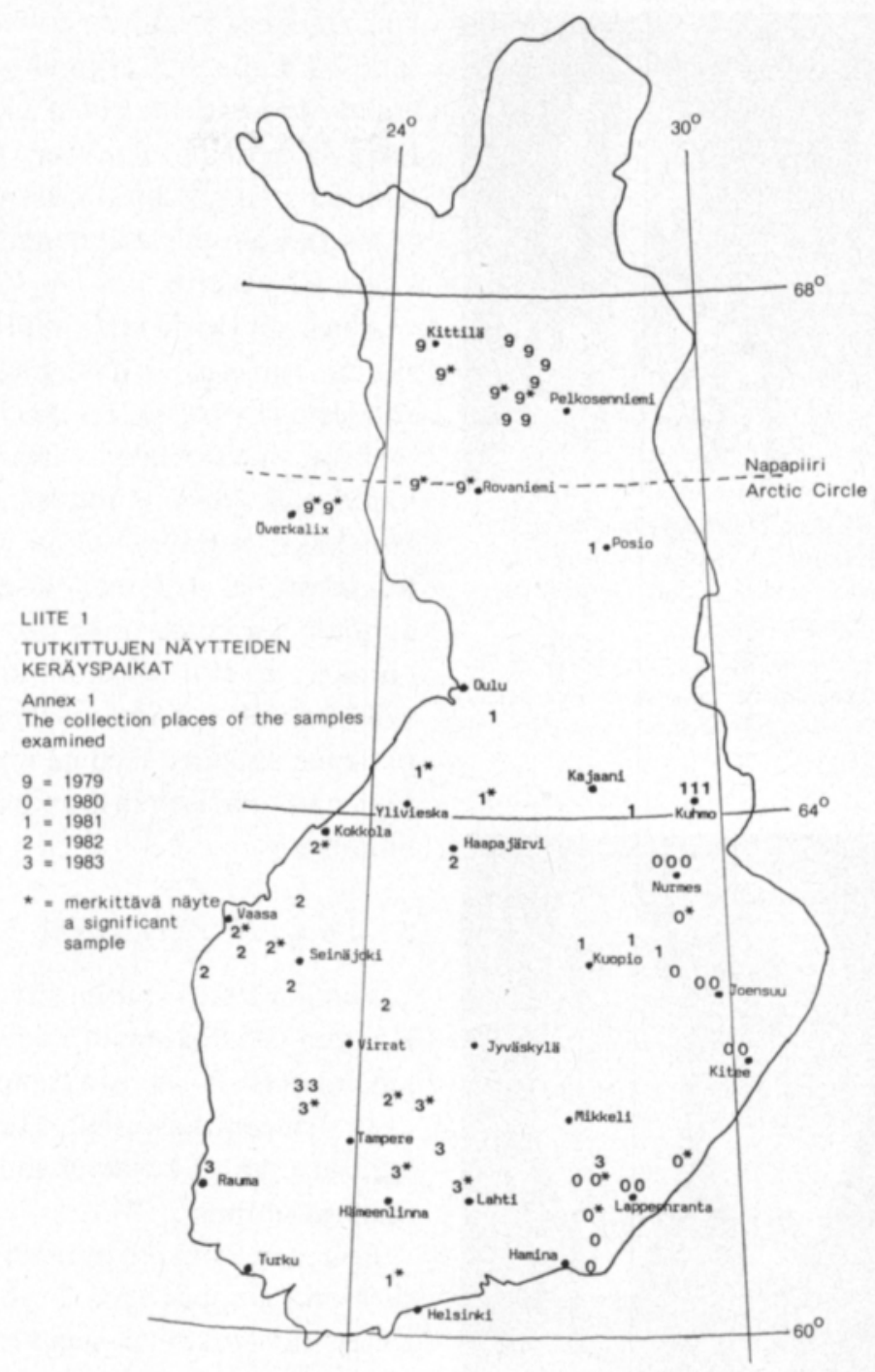

kerätyn näytteen koostumus on varsin moninainen. Siinä pieninä määrinä esiintyvät 4-tahoinen c ja d sekä 2-tahoisen loittotyypin a, b ja c ovat ilmeisesti maatiaisperua (Kuva 2). Mielenkiintoinen on myös 6-tahoinen c-ohra, joka on harvinaista pilosum-tyyppiä. Näyte nro 20 sekä Rautjärveltä kerätystä näytteestä nro 21 löytynyt 4-tahoinen d-ohra lienevät myös maatiaisperua. Viimeisenä taulukossa on kevätruisnäytteestä poimittu harvinainen 4-tahoinen b-tyypin ohra.

\section{Vuosi 1981 (Taulukko 3)}

Vuonna 1981 kerättiin näytteitä Pohjois-
Savosta ja Oulun läänin alueelta. Onpa joukossa näyte Etelä-Suomestakin (Liite 1). Saadusta ohra-aineistosta siementarkastuslaitos tutki 12 näytettä.

Otra oli aineiston valtalajike, parissa näytteessä oli Tammi-ohraa ja kaksi näytettä oli Pirkkaa. Lajikkeiksi tunnistamattomassa aineistossa oli valtaosa 4-tahoista d-tyypin ohraa, joskin vain näytteillä 33 ja 34 on merkitystä muiden ollessa itämättömiä. Näytteistä mielenkiintoisin on Vihdistä kerätty, Vega- tai Ollinohraksi mainittu näyte 43. Tämä osoittautui maatiaistyyppiseksi 2-tahoiseksi loittoohraksi, joka oli pääosaltaan a-tyyppiä, mutta sisälsi myös b- ja c-tyyppejä (Kuva 3). 


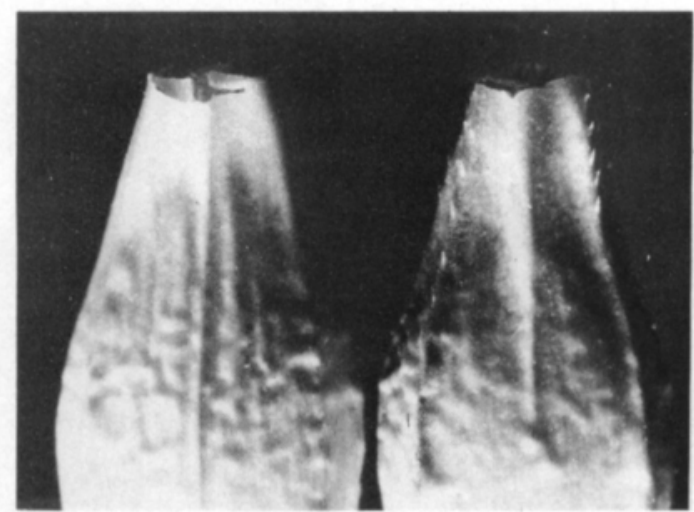

Kuva 2. Näytteen 16 kaksitahoisella b-tyypillä (oik.) jyvăn sivuselkäsuonien văkäset ovat hyvin voimakkaat. Vasemmalla saman näytteen kaksitahoinen c-tyypin jyvä.

Fig. 2. The 2-rowed b-type (right) from sample 16 has very strong spicules on inner lateral nerves of lemma. A 2-rowed c-type grain from the same sample to the left.

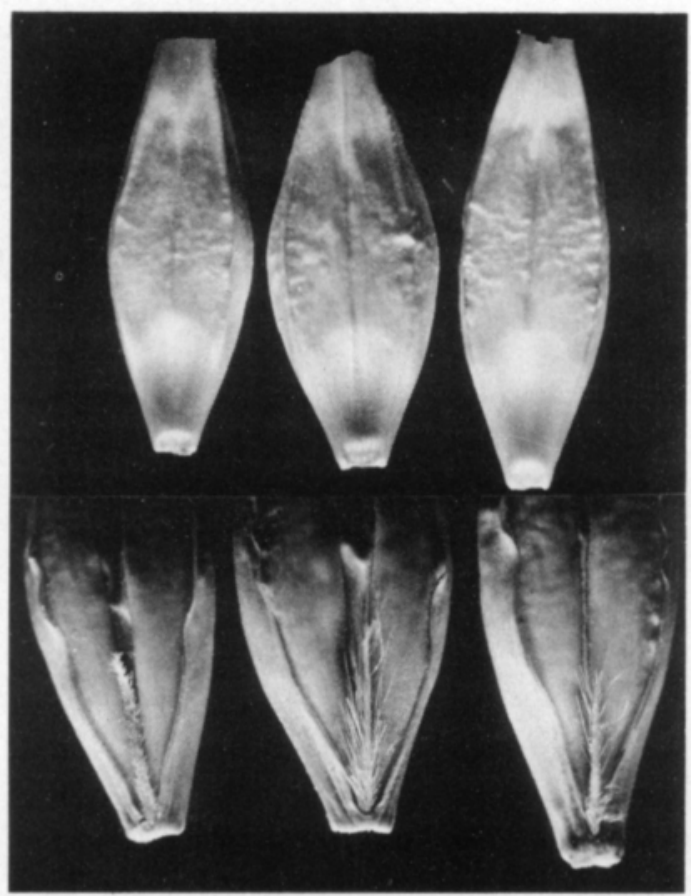

Kuva 3. Näytteen 43 tyyppikoostumus: a (oik.), b ja c. Fig. 3. The type composition of the sample 43: $a$ (right), $b$ and $c$.

\section{Vuosi 1982 (Taulukko 4)}

Vuoden 1982 aineisto kerättiin pääosaltaan läntiseltä Etelä-Pohjanmaalta, mutta joitakin näytteitä on keskemmältä Suomea (Liite 1).
Ohranäytteistä valtion siementarkastuslaitos tutki 10. Lajike- tai tyyppikoostumusta ei ole esitetty prosentteina kuten aikaisemmissa taulukoissa, koska päälajikkeen tai tyypin osuutta ei näytteitä analysoitaessa laskettu. Näytteissä runsaimmin esiintynyt lajike on taulukossa alleviivattu.

Aineiston yleisin lajike on Pirkka. Myös Otraa on runsaasti joskin päälajikkeena vain kahdessa näytteessä. Lajikkeiksi tunnistamattomassa aineistossa on 4-tahoinen d-ohra nytkin yleisin. Mielenkiintoisimmat ovat taulukon kaksi ensimmäistä ja viimeinen näyte, joissa on selvästi maatiaisperäistä ainesta. Juupajoelta kerätyn näytteen nro 53 Helmiohraksi arveltu pääkomponentti todettiin Louhi-ohraksi. Tämä näyte on varsin monipuolinen sisältäen hieman myös "väliohraa", joka on 2-tahoisen ja monitahoisen ohran välimuoto.

\section{Vuosi 1983 (Taulukko 5)}

Vuonna 1983 kerättiin näytteitä pääosiltaan Hämeen ja Satakunnan alueilta; yksi näyte on kuitenkin Etelä-Savosta (Liite 1). Ohra-aineistosta siementarkastuslaitos tutki 7 näytettä sekä lisäksi kaksi kevätvehnänäytteistä erottamaansa ohraa.

Poiketen kaikkien muiden vuosien keräyksistä on painopiste nyt 2-tahoisessa ohrassa. Kuten muidenkin vuosien keräyksissä oli monissa näytteissä 4-tahoista d-tyypin ohraa. Kolme näytettä oli pääosaltaan Pirkka-ohraa; joukossa hieman myös Otraa ja Hankkija673-ohraa. Kaksitahoisista oli yksi näyte pääosaltaan Balder-ohraa ja yksi, Hämeenkyröstä kerätty ja Halikonohraksi mainittu samaa tyyppiä kuin Halikonohra I. Tämän lisäksi aineistosta ovat säilyttämisen arvoisia näytteet 55,58 ja 61 , jotka mitä ilmeisimmin ovat maatiaisperuisia. Näistä erityisesti näytteen 58 tyyppikoostumus on varsin monipuolinen.

\section{Samaa tyyppiä olevien ohrien vertailua (Taulukko 6)}

Samaa tyyppiä olevien ohrien muoto-opillista vertailua koekentällä suoritettiin vähäi- 
sessä määrässä jokaisena tutkimusvuonna, mutta perusteellinen, kaikkien vuosien keräysaineistosta erotettujen tyyppien vertailu tapahtui kasvukausina 1984 ja 1985 . Näytteet, jotka tai joista erotettuja tyyppejä oli otettu vertailuun, on esitetty taulukossa 6. Näytteiden numerot ovat samat kuin taulukoissa $1-5$. Myös näytteessä olevat lajikkeet tai tyypit on numeroitu. Osanäytteen tunnuksena seuraavissa selostuksissa on näytteen numero/lajiketai tyyppinumero.

Valitettavasti varsinkin vuosi 1984 oli vertailututkimukselle epäedullinen. Kasvustot lakoutuivat hyvin varhaisessa vaiheessa maata myöten, mikä suuresti vaikeutti tutkimusta. Kasvustojen kehitys ja pituus on esitetty taulukoissa 7 ja 8 .

\section{6-taho-ohra (Taulukko 7)}

Saalis 6-taho-ohrien osalta jäi peräti niukaksi, koska yhtä lukuun ottamatta kaikki tämän ryhmän edustajat voitiin tunnistaa lajikkeiksi. Ohra 16/1 oli varsin lyhyt- ja tiheätähkäinen.

\section{4-taho-ohrat a-c (Taulukko 7)}

Nelitahoista a-ohraa löytyi vain yhdestä näytteestä ja c-ohraa kahdesta näytteestä. Geneettisesti c-ohrat poikkesivat toisistaan mm. kehitysrytmin osalta.

Nelitahoista b-tyyppiä löytyi 5 ohranäytteestä; myös eräästä kevätruisnäytteestä (31) erotettu ohra oli tätä tyyppiä. Aineiston ominaisuuksissa oli varsin vähän eroja. Kaikki olivat pitkä- ja heikkokortisia, joskin n. $20 \mathrm{~cm}$ :n pituuseroja voitiin havaita. Myös kasvurytmissä oli eroavuutta. Näytteet $1 / 3,12 / 3$ ja $45 / 3$ olivat hyvin samanlaisia muistuttaen ohraa, jota poikkeavana tyyppinä tavattiin aikanaan Pirkka-ohrasta. Keskenään varsin samankaltaiset näytteet $2 / 3$ ja $31 / 3$ poikkesivat edellisen ryhmän ohrista kasvuston runsaamman antosyaanipitoisuuden perusteella. Edellisistä täysin poikkeava oli näyte $44 / 3$. Kaleiden vihneet olivat tällä ohralla lyhyemmät kuin yleensä 4-taho-ohrilla ja jyvät olivat ly-

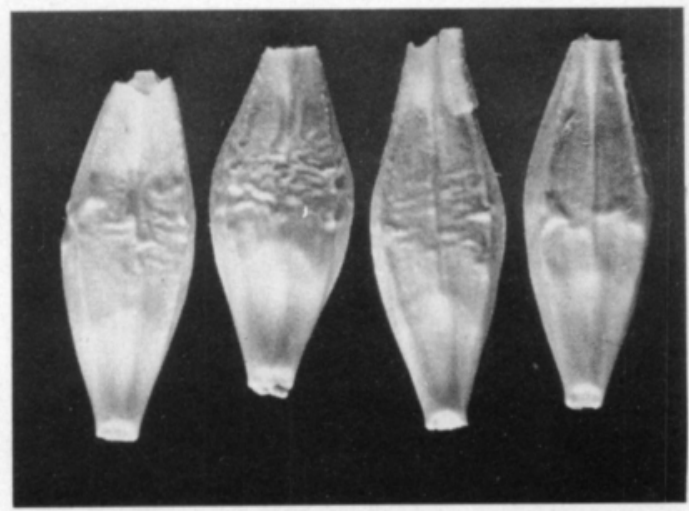

Kuva 4. Eri năytteiden 4-tahoisia b-ohria: 12 (oik.), 31, 44 ja 45.

Fig. 4. 4-rowed barleys of b-type from different samples: 12 (right), 31,44 and 45.

hyitä ja varsin pulleita sekä niiden sivuselkäsuonten väkäset hyvin voimakkaat (Kuva 4).

\section{4-tahoiset d-ohrat (Taulukko 8)}

Kuten edellä on jo todettu, muodostivat 4-tahoiset d-ohrat lajikkeeltaan tuntemattoman aineiston pääosan. Niinpä niitä tyyppivertailussa oli peräti 19 näytettä.

Näytteet 13 ja 14 olivat muita aikaisempia, toistensa kaltaisia ja voitiin kutakuinkin luotettavasti todeta ruotsalaiseksi Ảsa-ohraksi. Muu aineisto oli perustyypiltään varsin samanlaista, maatiaisohraan vivahtavaa. Korsi oli varsin pitkä ja heikko, tähkä harva. Kehityksen rytmissä voi havaita vähäistä korrelaatiota kasvualueen kanssa. Aikaisin aineisto oli pohjoisesta kerättyä, joskin aikaisuushavaintoja pikkuruuduilla vaikeutti ruutujen erilainen tiheys.

Pohjoisen ohrista ovat $1 / 5,2 / 5,11 / 5$ ja $12 / 5$ varsin samanlaisia. Niitä tummemman vihreä ja pystykasvuisempi oli näyte 10/5. Etelämpää Suomea kerätyistä ohrista muistuttivat näytteet $16 / 5,20 / 5,44 / 5$ ja $53 / 5$ toisiaan. Yhteistä niille oli lisäksi, että alkuperäiset näytteet useimmiten sisälsivät myös maatiaistyyppistä 2-taho-ohraa. Näyte 21/5 poikkesi muista tähkälapakon rakenteen puolesta. Se oli myös aikaisin etelämpää Suomea kerätyistä ohrista. Oulun läänistä kerätyt 33/5 


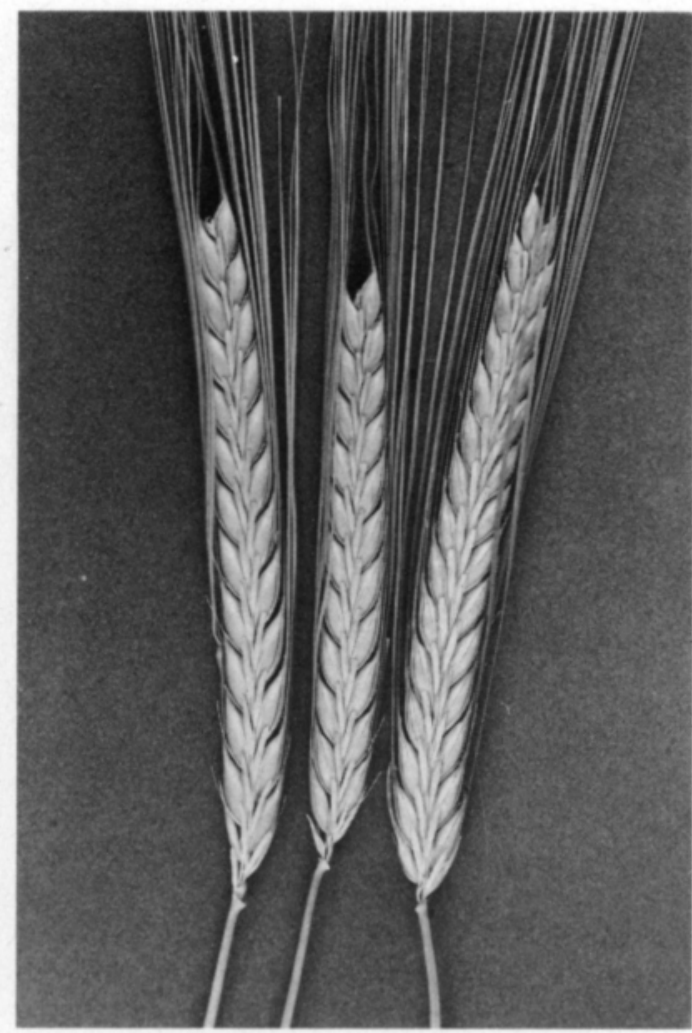

Kuva 5. Tyypillisiä aineiston 2-tahoisen loitto-a-ohran tähkiä näytteestä 43 .

Fig. 5. Typical ears of 2-rowed nutans a-type barley from the sample 43.

ja 34/5 todettiin keskenään samankaltaisiksi samoin myös Pohjanmaalta kerätyt näytteet $45 / 5$ ja 49/5. Jälkimmäisten näytteiden alkukehitys oli varsin nopea, mutta tuleentuminen myöhästyi, osittain pahan lakoontumisen takia. Myöhäisimmän 4-tahoisen d-tyypin aineiston muodostivat näytteet $55 / 5,58 / 5$ ja $61 / 5$. Ohrat olivat toistensa kaltaisia ja yhteistä oli myös näytteiden, josta ne oli erotettu, muu sisältö.

\section{2-tahoinen loitto-ohra a ja c (Taulukko 7)}

Useimmat 2-taho-ohrat, joita näytteistä löydettiin, sisälsivät paitsi tyyppiä a myös tyyppiä c. Vertailussa osoittautuivat näytteiden 43 , 55,58 ja 61 sekä a-tyypit keskenään että ctyypit keskenään varsin samankaltaisiksi. Aineistojen alkuperä on ilmeisesti sama muistuttaen varsin paljon ensimmäistä suomalaista

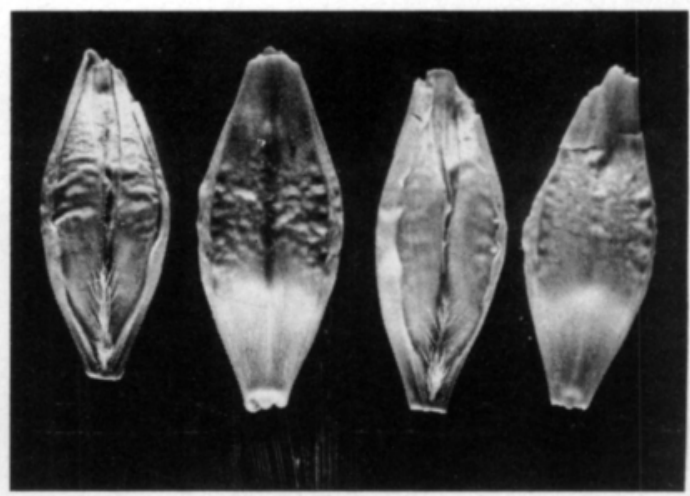

Kuva 6. Halikonohraksi mainitun năytteen 59 jyvăt ( 2 kpl oikealla) ja lajikkeen jalostajalta 1920luvulla saadun Halikonohran verrannenäytteen jyvăt.

Fig. 6. The 2 grains of the sample 59, mentioned $\mathrm{Ha}$ likonohra, (on the right) and standard grains of Halikonohra recieved from the breeder of the cultivar in the 1920's.

ohralajiketta Piikkiönohraa, joka tuli kauppaan v. 1922. Piikkiönohran päätyyppi on $a$, mutta valtion siementarkastuslaitoksen tarkastajan Elli Korpisen aikanaan tekemien julkaisemattomien havaintojen mukaan sisälsivät useimmat näytteet myös c-tyyppiä. Tutkitut a- ja c-ohrat olivat myös keskenään varsin samanlaisia. Korsi oli pitkä ja heikko sekä tähkä pitkä, harva ja kapea (Kuva 5).

Näyte 59, Halikonohraksi mainittu, muistutti suuresti edellä mainittuja a-ohria. Se oli niitä kuitenkin hieman isojyväisempi (Kuva 6). SAULI (1925) mainitsee Halikonohran melko tiheätähkäiseksi ja isojyväiseksi lajikkeeksi.

Näytteiden 16, 44 ja 53 a-ohrat poikkesivat selvästi edellisistä sekä myös toisistaan (Kuva 7). Komponentissa $53 / 7$ voi olla Helmiohraa, mutta asiaa ei pystytty varmistamaan.

2-tahoinen loitto-ohra b ja d (Taulukko 7)

Kaksitahoista b- tai d-tyypin loitto-ohraa oli aineistossa hyvin vähän, edellistä kahdessa, jälkimmäistä yhdessä näytteessä. Jokainen niistä oli perimältään erilainen. Ohrassa 58/10 sivuselkäsuonien väkäset olivat varsin heikkoja. Näyte vivahti myös lievästi pilosum-tyyppiin. 


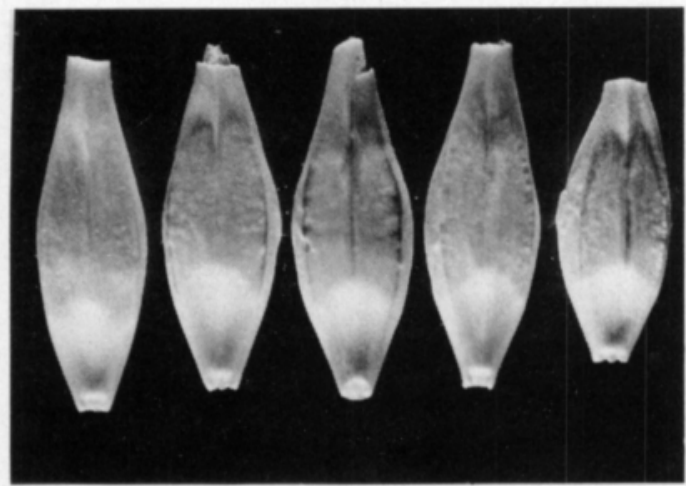

Kuva 7. Eri näytteiden 2-tahoisia a-ohria: 16 (oik.), 43, 53,55 ja 58 .

Fig. 7. 2-rowed a-type barleys from different samples: 16 (right), 43, 53, 55 and 58.

\section{Tiivistelmä}

Pohjoismaiden Geenipankin vuosina 1979 -83 keräämistä ohranäytteistä valtion siementarkastuslaitos tutki 62 (Taulukot $1-5$ ).

\section{Kirjallisuutta}

Hunter, H. 1952. The barley crop. 187 s. Crosby Lockwood a. Son., London.

KORPINEN, E. 1943. Ohran morfologisista ominaisuuksista. Maatal.tiet. Aikak. 15: 49-63.

SAULI, J.O. 1925. Laatuselitys kauppaan lasketuista Tammiston jalosteista. Hankkijan Siemenjulkaisu 1925: 110-114.

- 1927. Suomen maatiaisohrat ja niiden jalostusarvo.
Näistä merkittävimpien lajike- tai tyyppikoostumus on esitetty taulukossa 6 . Taulukkoon otetut 22 näytettä, siis noin $36 \%$ tutkituista näytteistä sisältänevät perintötekijöitä, joita ei ole muualta saatavissa. Loput tutkituista näytteistä olivat vielä käytettävissä olevia, nimettyjä lajikkeita, yleisimpinä Otra ja Pirkka tai itävyytensä jo menettänyttä tavaraa.

Taulukon 6 pääryhmän muodostavat erityyppiset 4-taho-ohrat. Näytteet 13 ja 14 ovat melko luotettavasti Åsa-ohraa. Myös muissa voi olla vanhojen lajikkeiden (Lapinohra, Pertunohra, Vega, Edda, Ảsa ym.) aineistoa, mutta pääosaltaan ne lienevät maatiaisperua. Kuten alustavat tyyppikohtaiset vertailut osoittavat (Taulukot 7-8) on aineisto yleispiirteiltään varsin samankaltaista, mutta vaihteluakin löytyy sekä näytteiden välillä että sisällä. Taulukon 2-taho-ohrissa on vallitsevana tyyppi, joka varsin paljon muistuttaa maatiaisohrasta valittua Piikkiönohraa.

Suom. Maatal.tiet. Seur. julk. 16: 1-139.

ULVINEN, O. 1963. Suomessa viljeltyjen ohralajikkeiden systemaattinen asema. Maatal.tiet. Aikak. 35: 127-137. - 1972. Pomo- ja Etu-ohrien tunnistaminen. Maatal.tiet. Aikak. 44: 41-48.

Käsikirjoitus saapunut 20. 2. 1986 


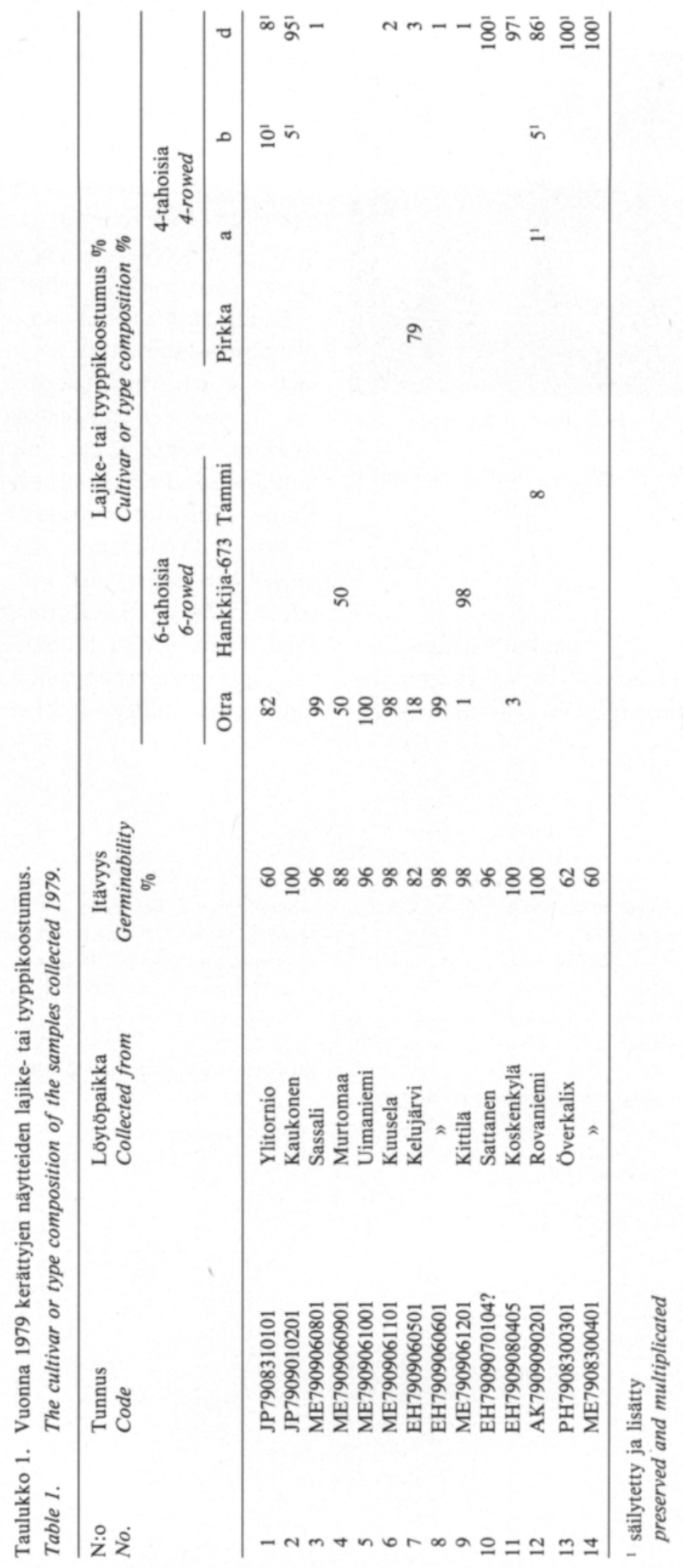




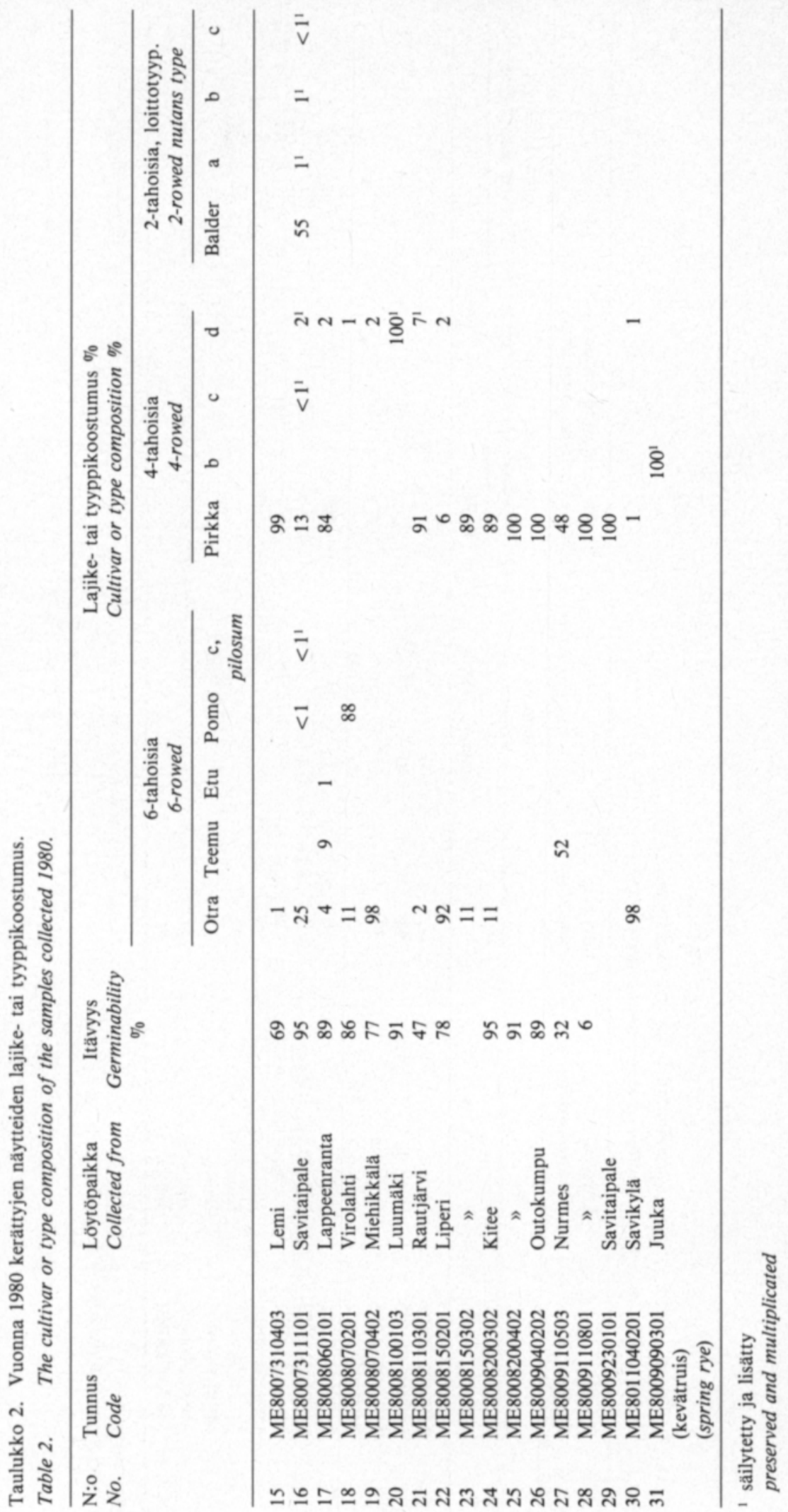




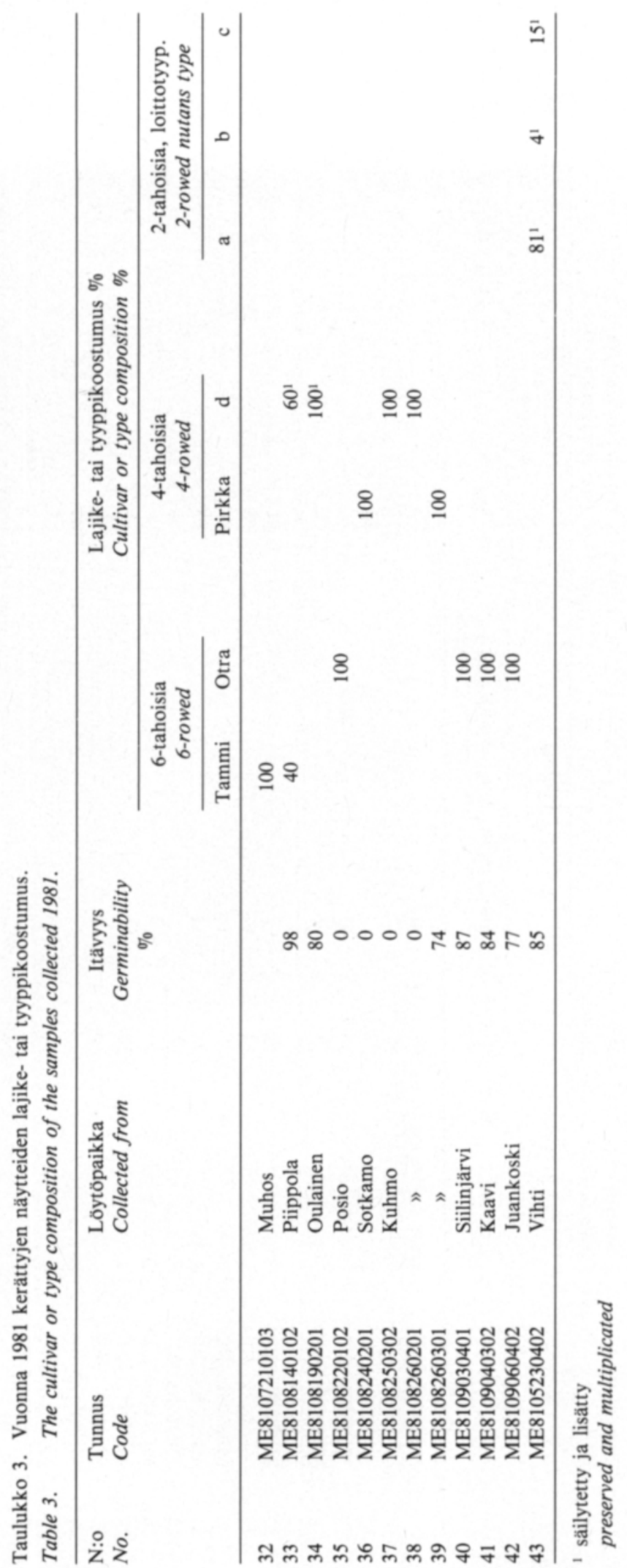




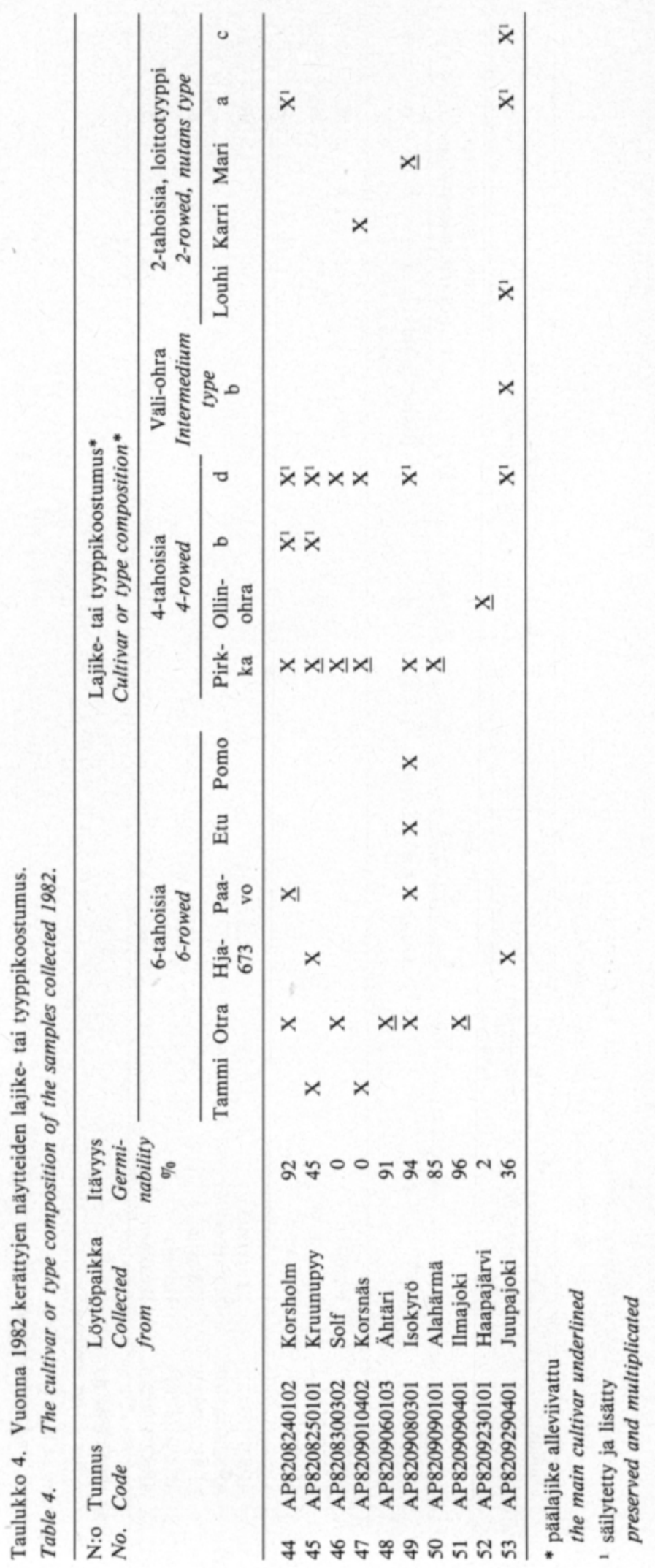




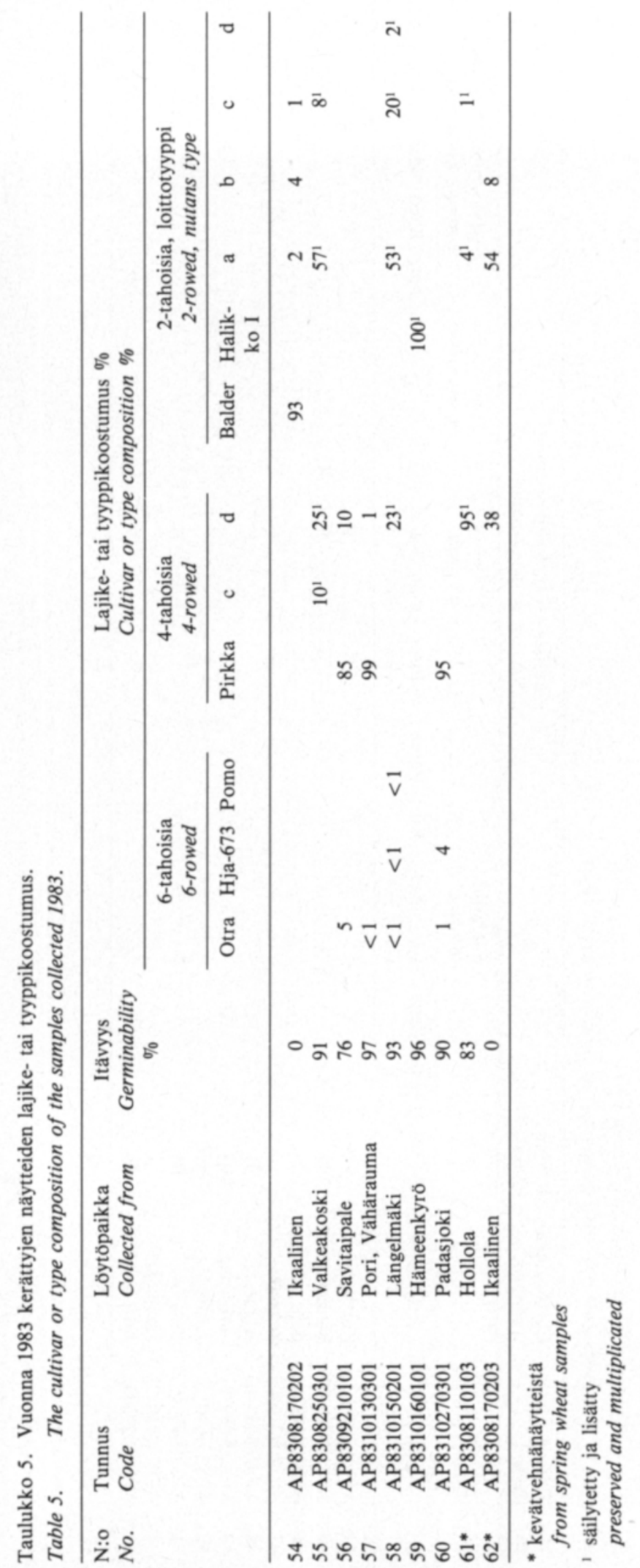




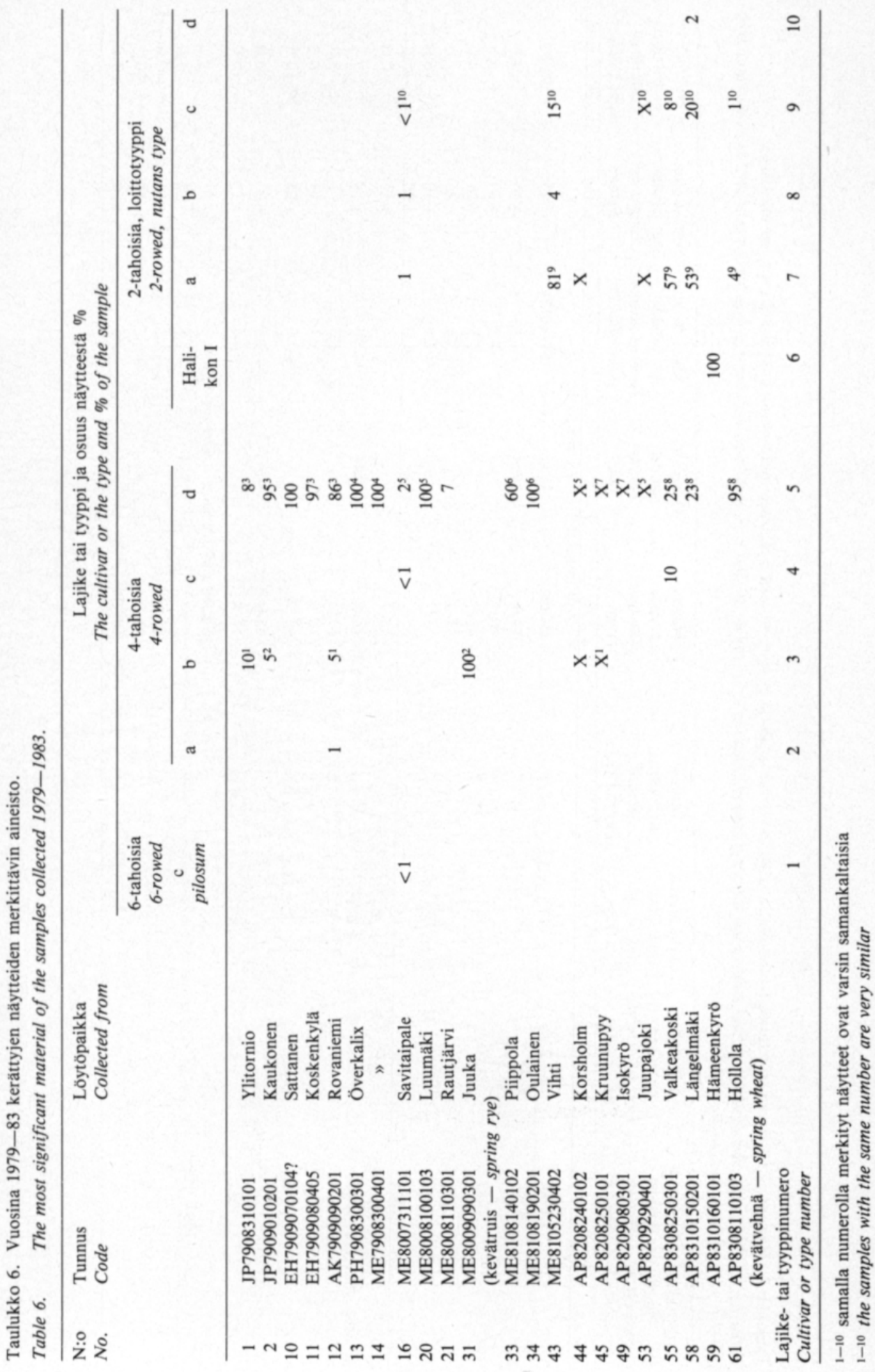




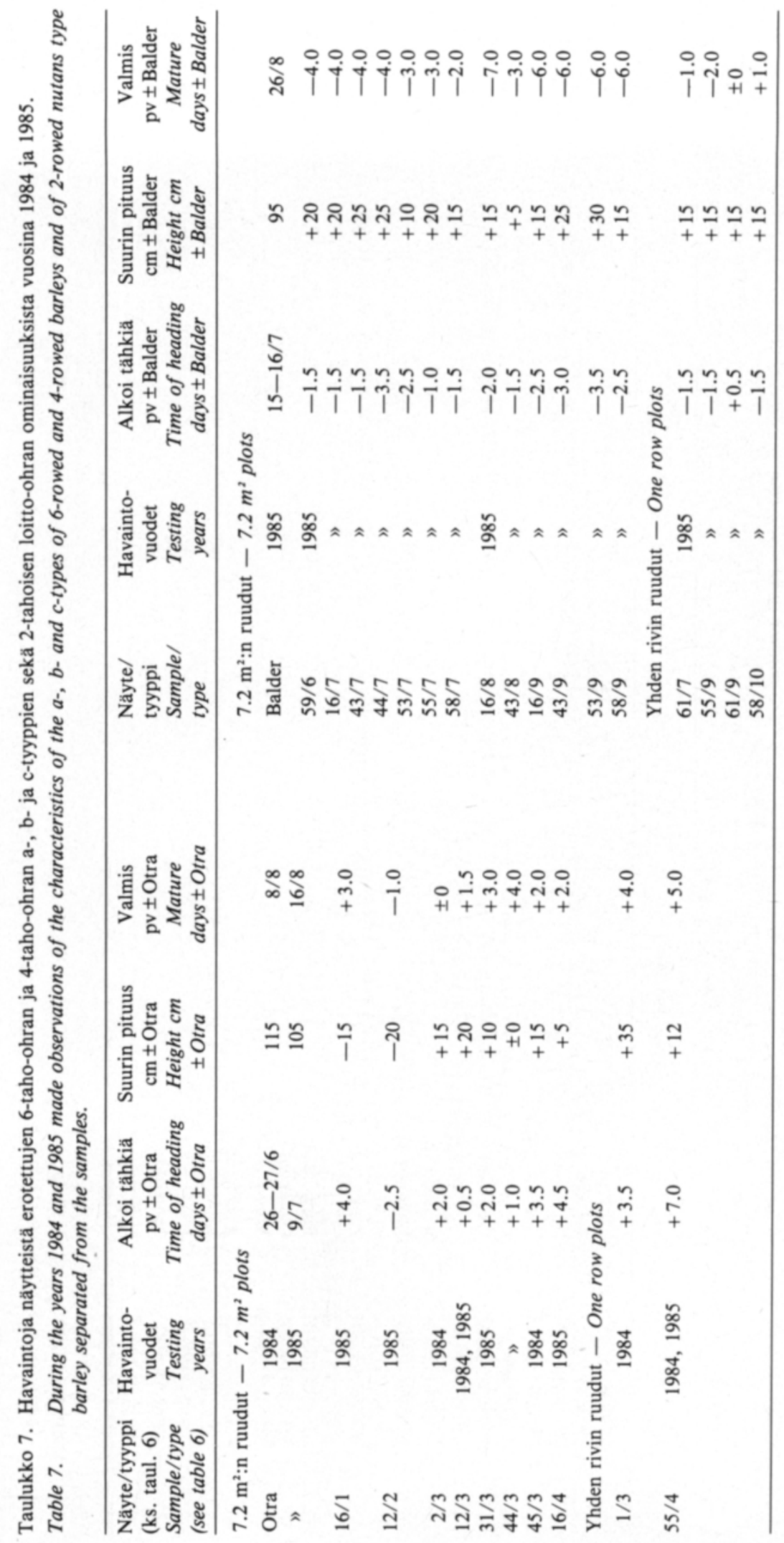




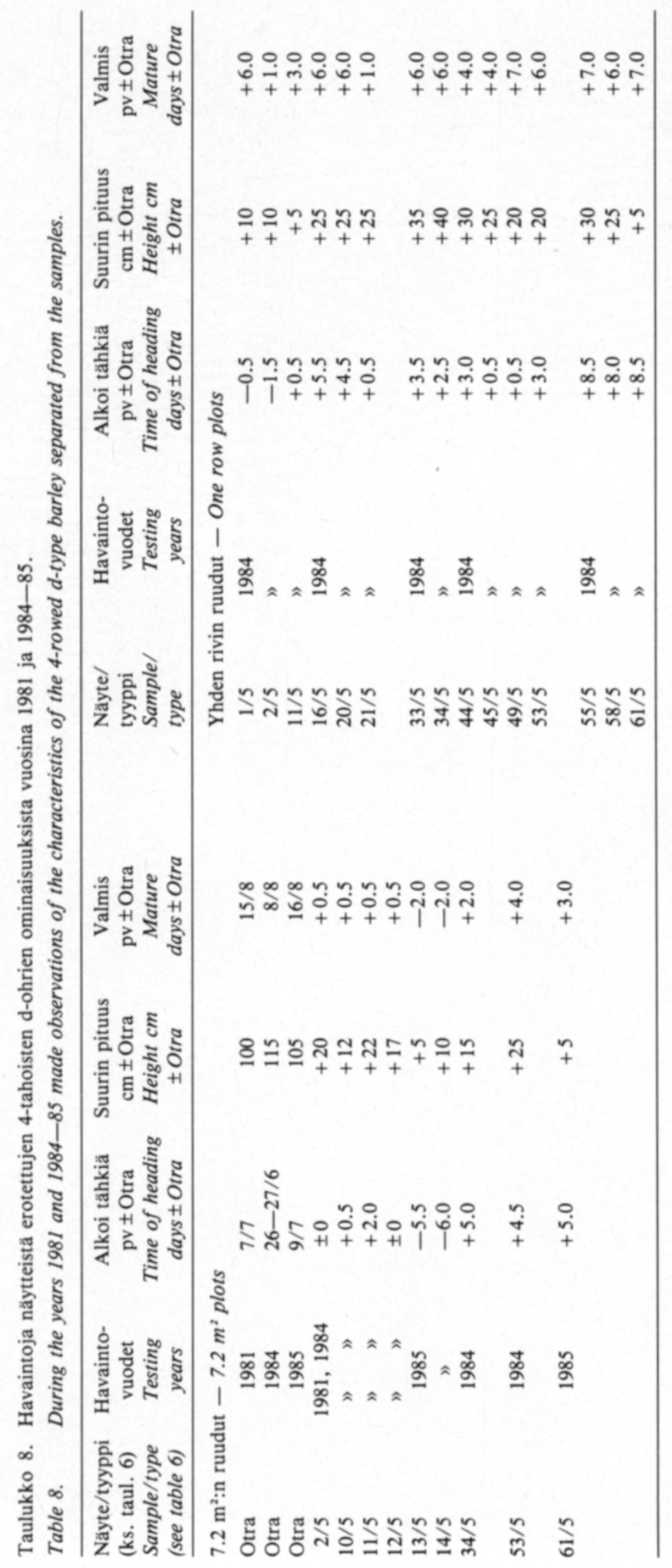

